\title{
TROPICAL AND PARASITIC INFECTIONS IN THE INTENSIVE \\ CARE UNIT
}




\section{PERSPECTIVES ON CRITICAL CARE INFECTIOUS DISEASES \\ Jordi Rello, M.D., Series Editor}

1. N. Singh and J.M. Aguado (eds.): Infectious Complications in Transplant Recipients. 2000. ISBN 0-7923-7972-1

2. P.Q. Eichacker and J. Pugin (eds.): Evolving Concepts in Sepsis and Septic Shock. 2001. ISBN 0-7923-7235-2

3. J. Rello and K. Leeper (eds.): Severe Community Acquired Pneumonia. 2001. ISBN 0-7923-7338-3

4. R.G. Wunderink and J. Rello (eds.): Ventilator Associated Pneumonia. 2001. ISBN 0-7923-7444-4

5. R.A. Weinstein and M. Bonten (eds.): Infection Control in the ICU Environment. 2002. ISBN 0-7923-7415-0

6. R.A. Barnes and D.W. Warnock (eds.): Fungal Infection in the Intensive Care Unit. 2002. ISBN 1-4020-7049-7

7. A.R. Hauser and J. Rello (eds.): Severe Infections Caused by Pseudomonas Aeruginosa. 2003. ISBN 1-4020-7421-2

8. N.P. O'Grady and D. Pittet (eds.): Catheter-Related Infections in the Critically Ill. 2004. ISBN 1-4020-8009-3

9. C. Feldman and G. Sarosi (eds.): Tropical and Parasitic Infections in the Intensive Care Unit. 2005. ISBN 0-387-23379-2 


\section{TROPICAL AND PARASITIC INFECTIONS IN THE INTENSIVE CARE UNIT}

edited by

Charles Feldman, MB BCh., PhD, FRCP, FCP (SA).

Division of Pulmonology,

Department of Medicine,

Johannesburg Hospital, and

University of the Witwatersrand,

Johannesburg, South Africa.

and

George A. Sarosi, M.D., M.A.C.P.

Indiana University School of Medicine, and Medical Service,

Veterans Administration Medical Center,

Indianapolis, USA 
eBook ISBN: $\quad 0-387-23380-6$

Print ISBN: $\quad 0-387-23379-2$

C2005 Springer Science + Business Media, Inc.

Print @2005 Springer Science + Business Media, Inc.

Boston

All rights reserved

No part of this eBook may be reproduced or transmitted in any form or by any means, electronic, mechanical, recording, or otherwise, without written consent from the Publisher

Created in the United States of America

Visit Springer's eBookstore at:

http://ebooks.springerlink.com

and the Springer Global Website Online at: http://www.springeronline.com 
Contributors vii

Preface xi

Charles Feldman and George Sarosi

1. Severe Malaria 1

South African Perspective

Lucille Blumberg

2. Severe Malaria: North American Perspective

North American Perspective

Monica E. Parise, and Linda S. Lewis

3. Viruses in the Intensive Care Unit (ICU)

South African Perspective

Guy A. Richards, Gunter Schleicher and Mervyn Mer

4. Viral Infections in ICU Patients

North American Perspective

David E. Greenberg, and Stephen B. Greenberg

5. Tuberculosis in the Intensive Care Unit

South African Perspective

Charles Feldman

6. Tuberculosis in the Intensive Care Unit: The North American Perspective

North American Perspective

Loren C. Denlinger, and Jeffrey Glassroth 
South African Perspective

Alan S. Karstaedt, L. Rhudo Mathivha, Christine

L.N. Banage

8. HIV Infection and Associated Infections in the Intensive Care Unit: Perspectives from North America

North American Perspective

Scott E. Evans and Andrew H. Limper

9. African Trypanosomiasis

South African Perspective

Hayden T. White

10. Parasitic Infections in the ICU

South African Perspective

John Frean

11. Fungal Infections in the ICU

South African Perspective

Francois I. Venter and Ian Sanne

12. Endemic mycosis

North American Perspective

Chadi A. Hage, Kenneth S. Knox, George A.

Sarosi 


\section{CONTRIBUTORS}

Christine L. N. Banage, MB ChB, FCP (SA).

Intensive Care Department

Chris Hani Baragwanath Hospital,

Johannesburg, SOUTH AFRICA

Lucille Blumberg, MB BCh, MMED (Med Micro), DTM\&H, DOH, DCH.

National Institute for Communicable Diseases,

Johannesburg, SOUTH AFRICA

Loren C. Denlinger, M.D., PhD.

Division of Pulmonary and Critical Care,

Department of Medicine,

University of Wisconsin-Madison, and the University of Wisconsin Hospital and Clinics,

Madison, Wisconsin, USA

Scott E. Evans, M.D.

Division of Pulmonary, Critical Care Medicine,

and Internal Medicine,

Mayo Clinic and Foundation,

Rochester, Minnesota, USA

Charles Feldman, MB BCh, PhD, FRCP, FCP (SA).

Division of Pulmonology,

Department of Medicine

University of the Witwatersrand

Johannesburg, SOUTH AFRICA

John Frean, MB BCh, MMED (Path).

National Institute for Communicable Diseases,

National Health Laboratory Services,

Johannesburg, SOUTH AFRICA

Jeffery Glassroth, M.D.

Division of Pulmonary and Critical Care,

Department of Medicine,

University of Wisconsin-Madison, and the University of Wisconsin Hospital and Clinics, Madison, Wisconsin, USA 


\section{David E. Greenberg, M.D.}

NIAID, Laboratory of Infectious Diseases,

Bethesda, Maryland, 20892, USA

Stephen B. Greenberg, M.D.

Department of Medicine,

and Department of Molecular Virology and Microbiology,

Baylor College of Medicine,

Houston, Texas, 77030, USA

\section{Chadi A. Hage, M.D.}

Indiana University-School of Medicine,

Indianapolis, IN, USA

\section{Alan S. Karstaedt, MB BCh, MMED (Int Med), DTM\&H.}

Division of Infectious Diseases

Department of Medicine,

Chris Hani Baragwanath Hospital

University of the Witwatersrand,

Johannesburg, SOUTH AFRICA

\section{Kenneth S. Knox, M.D.}

Indiana University-School of Medicine,

and Richard L. Roudebusch VA Medical Center,

Indianapolis, IN, USA

\section{Linda S. Lewis, D.V.M., M.P.V.M.}

Health Studies Consulting

Medford, OR 97501, USA

\section{Andrew H. Limper, M.D.}

Division of Pulmonary, Critical Care Medicine

and Internal Medicine,

Mayo Clinic and Foundation,

Rochester, Minnesota, USA

\section{Rudo Mathivha, MB ChB, FCP (Critical Care). \\ Intensive Care Department \\ Chris Hani Baragwanath Hospital, Johannesburg, SOUTH AFRICA}


Mervyn Mer MB BCh, MMED (Int Med), FCP (SA).

Division of Pulmonology,

Department of Medicine

University of the Witwatersrand

Johannesburg, SOUTH AFRICA

Monica E. Parise, M.D.

Malaria Epidemiology Branch

Division of Parasitic Diseases

National Center for Infectious Diseases

Center for Disease Control and Prevention

Atlanta, GA 30341-3717, USA

Guy A. Richards MB BCh, PhD, FRCP, FCP (SA).

Intensive Care Unit,

Johannesburg Hospital

Department of Medicine,

University of the Witwatersrand,

Johannesburg, SOUTH AFRICA

Ian M. Sanne MMB BCh, FCP (SA), DTM\&H.

Clinical HIV Research Unit

University of the Witwatersrand,

Johannesburg, SOUTH AFRICA

George A. Sarosi, M.D., M.A.C.P.

Indiana University-School of Medicine, and Roudebusch VA Medical Center, Indianapolis, IN, USA

Gunter Schleicher MB BCh, MMED (Int Med), FCP (SA).

Division of Pulmonology,

Department of Medicine

University of the Witwatersrand

Johannesburg, SOUTH AFRICA

W. D. Francois Venter MB BCh, FCP (SA), DTM\&H.

Reproductive Health Research Unit, University of the Witwatersrand, Johannesburg, SOUTH AFRICA 
Hayden T. White, MB BCH, MMED (Int Med), FCP (SA).

Division of Pulmonology,

Department of Medicine

University of the Witwatersrand

Johannesburg, SOUTH AFRICA 


\section{PREFACE}

The term tropical infection is most commonly used to describe an infection occurring in an individual living in the geographical area between the Tropic of Cancer and the Tropic of Capricorn. Both developing and developed countries fall within these equatorial parallels. It is said that the common feature that allows the specific pathogens to flourish in these areas is the hot and humid climate. While a myriad of different micro-organisms may cause tropical infections, many of these infections are caused by a relatively small number of common bacteria, mycobacteria, viruses, fungi and parasites. Several of these infections may also cause critical illness. Human immunodeficiency virus (HIV) infection is also found commonly in many of these tropical countries and so there is considerable overlap between HIV infection and tropical infections.

In the past many of these infections may have been confined to these tropical areas of the world. However, with the increase in air travel and tourism and the changing patterns of immigration, an increasing number of individuals are coming into contact with these infectious agents and transmission across the world has been enhanced. Such infections are therefore being seen more often and treated in apparently unusual locations. For these reasons this reference volume entitled "Tropical and Parasitic Infections in the Intensive Care Unit" provides an important overview of those infections that may cause critical illness. A unique aspect of this series of volumes is the individual reviews given by authors from different parts of the world, imparting their own perspectives to each of the chapters.

Charles Feldman

George Sarosi

Book Editors 